\title{
Antibiotic-resistant bacteria inhibited by extracts and fractions from Brazilian marine sponges
}

\author{
Palloma R. Marinho, ${ }^{1}$ Guilherme R. S. Muricy, ${ }^{2}$ Mara F. L. Silva, ${ }^{1}$ \\ Marcia Giambiagi deMarval, ${ }^{1}$ Marinella S. Laport ${ }^{*}, 1$
}

\author{
${ }^{1}$ Instituto de Microbiologia Prof. Paulo de Góes, Universidade Federal do Rio de Janeiro, Bloco I, CCS, Cidade \\ Universitária, Avenida Carlos Chagas Filho, 373, 21491-590 Rio de Janeiro-RJ, Brazil \\ ${ }^{2}$ Departamento de Invertebrados, Museu Nacional, Universidade Federal do Rio de Janeiro, Quinta da Boa Vista s/n, \\ São Cristóvão, 20940-040 Rio de Janeiro-RJ, Brazil.
}

\begin{abstract}
RESUMO: "Bactérias resistentes a antibióticos inibidas por extratos e frações de esponjas marinhas do Brasil”. O número crescente de bactérias resistentes aos antibióticos tem se tornado um sério problema médico nos últimos anos. As esponjas marinhas são uma fonte rica em compostos bioativos e muitas espécies podem ser úteis para o desenvolvimento de novos antimicrobianos. Esse estudo descreve uma triagem in vitro de esponjas para a pesquisa de novas substâncias contra bactérias resistentes. Os extratos de esponjas foram testados sobre 44 estirpes bacterianas, incluindo quatorze resistentes a antibióticos. Dez entre doze espécies de esponjas apresentaram atividade em um ou mais bioensaios. Os extratos aquosos de Cinachyrella sp. e Petromica citrina apresentaram um amplo espectro de ação sobre estirpes bacterianas resistentes, tais como, Staphylococcus aureus, Staphylococcus coagulase-negativos e Enterococcus faecalis. O extrato aquoso de $P$. citrina foi fracionado e a fração aquosa apresentou atividade inibitória sobre estirpes de Staphylococcus. Esta fração, na concentração do CMI (16 $\mu \mathrm{g} / \mathrm{mL})$, demonstrou efeito bactericida sobre células de $S$. aureus na fase exponencial de crescimento. O mecanismo de ação da fração ainda não foi elucidado, mas nós observamos que esta afeta a síntese protéica de Staphylococcus. Nossos resultados demonstraram pela primeira vez que Petromica citrina é uma fonte potencial de novas drogas para o tratamento de infecções causadas por bactérias resistentes.
\end{abstract}

Unitermos: atividade antibacteriana, bactéria resistente a antibióticos, esponjas marinhas, Petromica citrina.

\begin{abstract}
The growing number of bacterial strains resistant to conventional antibiotics has become a serious medical problem in recent years. Marine sponges are a rich source of bioactive compounds, and many species can be useful for the development of new antimicrobial drugs. This study reports the in vitro screening of marine sponges in the search for novel substances against antibiotic-resistant bacteria. Sponge extracts were tested against 44 bacterial strains, including fourteen antibiotic-resistant strains. Ten out of the twelve sponge species studied showed activity in one or more of the bioassays. Aqueous extracts of Cinachyrella sp. and Petromica citrina showed a large action spectrum over resistant-bacteria such as Staphylococcus aureus, coagulase-negative staphylococci and Enterococcus faecalis. Aqueous extract of P. citrina was fractioned and aqueous fraction showed a greatest inhibitory activity on Staphylococcus strains. In addition, this fraction demonstrated a bactericidal effect on exponentially growing $S$. aureus cells at the MIC (16 $\mu \mathrm{g} /$ $\mathrm{mL}$ ). The mechanism of action of bioactive fraction is still unclear, but we showed that it affect protein biosynthesis of Staphylococcus. Our results demonstrated for the first time that $P$. citrina is a potential source of new drugs for the treatment of infections by antibiotic-resistant bacteria.
\end{abstract}

Keywords: antibacterial activity, antibiotic-resistant bacteria, marine sponges, Petromica citrina.

\section{INTRODUCTION}

The increasing prevalence of multi-resistant bacteria made the search of new antibacterial agents an important strategy for the establishment of alternative therapies in difficult handling infections (Berlinck et al., 2004). The incidence of methicillin-resistant Staphylococcus aureus (MRSA) and vancomycinresistant Enterococcus (VRE) infections continues to rise in National Nosocomial Infections Surveillance System hospitals (Farr, 2006). Methicillin-resistant staphylococci infections mainly caused by S. aureus (MRSA strains) 
and by coagulase-negative staphylococci (CNS) such as Staphylococcus epidermidis (MRSE) and Staphylococcus haemolyticus (MRSH) isolates have increased over the last two decades (Rice, 2006). These antibiotic-resistant strains of Staphylococcus spp. are the pathogens most frequently isolated from nosocomial bacteremias, with an attributable mortality rate ranging from $13 \%$ for CNS to $42 \%$ for MRSA. In these cases, the therapy is generally limited to the use of vancomycin and teicoplanin (Diekema et al., 2001; Weber et al., 2003). However, some Staphylococcus strains resistant to glycopeptides have been reported in Brazil and other countries. Community-acquired MRSA is also increasing (Zetola et al., 2005). The proportion of enterococci resistant to vancomycin continues to rise in hospital settings, with the overwhelming majority of infections due to Enterococcus faecium (NNIS, 2004). The search for new drugs against antibiotic-resistant bacteria is an area of great medical importance (Rice, 2006).

The potential of marine organisms as a source of new substances is huge and has been barely investigated. Marine species comprise approximately half of the total global biodiversity, and thus the sea offers many potential sources for discovery of novel compounds (Aneiros \& Garateix, 2004). The world ocean is considered the largest reservoir of natural molecules remaining to be evaluated for drug activity (Gerwick, 1987).

Marine sponges (Porifera) are sessile, filterfeeding invertebrates with limited physical defenses and highly developed chemical defenses against predators and larval settlement of other sessile organisms (e.g., Pawlik et al., 1995; Becerro et al., 2003; Wulff, 2006; Thoms \& Schupp, 2007). Marine sponges are among the richest sources of pharmacologically-active chemicals from marine organisms; they are known to produce many different compounds with antitumoral, antiviral, antifungal, and antibacterial activities (e.g., Kobayashi, 2000; Berlinck et al. 2004; Blunt et al. 2007; Seleghim et al. 2007).

Screenings of marine sponges for antibacterial activity led to the isolation and characterization of a wide range of active compounds, including some promising therapeutic leads (Munro et al. 1999; Berlinck et al. 2004; Mayer \& Hammann, 2004; Sipkema et al., 2005; Moura et al., 2006). Up to 800 antibiotic compounds have been isolated from marine sponges (Torres et al., 2002). In the continuing effort by the marine natural products community, many antibacterial agents have been identified from sponges. Despite the high number of marine natural products discovered, none of them has yet led to an antibacterial product, but many are currently under investigation. Recently, some examples of substances with antibacterial activity, as manzamine A and psammaplin A, isolated from marine sponges were reviewed for our group (Laport et al., 2009).

In contrast with the great number of compounds with general antibacterial activity found in sponges or associated microorganisms, relatively few substances active against antibiotic-resistant bacteria have been isolated from sponges. The Arenosclerins A-C and haliclonacyclamine $\mathrm{E}$ isolated from the Brazilian sponge Arenosclera brasiliensis inhibited growth of twelve antibiotic-resistant bacteria isolated from a hospital (Torres et al., 2002). Crude extracts of less than 3\% of 215 Brazilian sponge species tested showed activity against antibiotic-resistant bacteria (Seleghim et al., 2007).

So far, pure compounds isolated from one specie (Torres et al., 2002) and crude extracts of 215 species of Brazilian sponges have been investigated through bioassays against antibiotic-resistant bacteria (Seleghim et al., 2007). Although a growing number of studies investigated the cytotoxic, neurotoxic and antimicrobial activities of sponges from the Brazilian coast (Muricy et al., 1993; Rangel et al., 2001; Monks et al., 2002; Berlinck et al., 2004; Seleghim et al., 2007), most Brazilian sponges remain unstudied. The city of Rio de Janeiro harbours a sponge fauna distinct from that of other areas in Southeastern Brazil such as Arraial do Cabo and São Sebastião, were other screenings have been conducted (Monteiro \& Muricy, 2004). Many species from Rio de Janeiro therefore have not been tested so far for antibacterial activities, particularly against antibioticresistant bacteria. In this study we performed a screening for antibacterial activity of crude extracts or active fraction of marine sponges from Brazil against bacterial strains of medical importance.

\section{MATERIAL AND METHODS}

\section{Sponge sampling}

Samples of twelve sponge species (Table 1) were collected through SCUBA diving from 4-20 $\mathrm{m}$ depth at Praia Vermelha $\left(22^{\circ} 57^{\prime} \mathrm{S}-43^{\circ} 09^{\prime} \mathrm{W}\right)$ and Cagarras Archipelago $\left(23^{\circ} 01^{\prime} \mathrm{S}-43^{\circ} 11^{\prime} \mathrm{W}\right)$, both located in Rio de Janeiro, Southeastern Brazil.

Table 1. Species of marine sponges screened for antibacterial activity in this study.

\begin{tabular}{lc}
\hline \multicolumn{1}{c}{ Species } & Family \\
\hline Cinachyrella sp. & Tetillidae \\
Cliona celata complex & Clionaidae \\
Dragmacidon reliculatus & Axinellidae \\
Geodia corticostylifera & Geodiidae \\
Guitarra sepia & Guitarridae \\
Haliclona sp. & Chalinidae \\
Hymeniacidon heliophila & Halichondriddae \\
Mycale microsigmatosa & Mycalidae \\
Oceanapia nodosa & Phloeodictyidae \\
Petromica citrina & Desmanthidae \\
Polymastia janeirensis & Polymastiidae \\
Tedania ignis & Tedaniidae \\
\hline
\end{tabular}




\section{Crude sponge extract preparation}

After collection, the specimens were processed under aseptic conditions as follows: macro-organisms were removed from the fresh material and the specimens were weighted; 5-10 $\mathrm{g}$ of sponge was macerated in sterile distilled water or ethanol to obtain a final concentration of approximately $1 \mathrm{~g} / \mathrm{mL}$ of each crude extract. Extracts were centrifuged at $5.000 \mathrm{xg}$ for $5 \mathrm{~min}$ and the supernatant was filtered (Millipore $0.22 \mu \mathrm{m}$ ) and stored at $4{ }^{\circ} \mathrm{C}$.

\section{Bacterial strains and culture conditions}

Eighteen reference (Table 2) and 26 clinical (Table 3) strains were used as test organisms in the antibacterial activity assays. Bacteria were grown in BHI (Brain Heart Infusion - Difco) medium at $37^{\circ} \mathrm{C}$ for $18 \mathrm{~h}$.

\section{Assay for antibacterial activity}

Antibacterial activity of crude extracts from sponges $(200 \mathrm{mg} / \mathrm{mL})$ or fractions from bioassay-guided fractionation was determined against the growth of bacteria by the agar-diffusion method as described previously by Giambiagi-deMarval et al. (1990). Briefly, $20 \mu \mathrm{L}$ of the crude extracts or fractions were spotted on BHI-agar. After growth of each strain at $37^{\circ} \mathrm{C}, 105$ cells of the indicator strains in BHI soft agar were poured over the plates. Plates were incubated at $37^{\circ} \mathrm{C}$ for $18 \mathrm{~h}$ and the inhibition zones around the spotted strain were observed. Inhibition zones $\geq 8 \mathrm{~mm}$ were considered indicative of inhibitory activity. Since the aqueous extract of Petromica citrina presented the largest action spectra and very little date about this specie were published, it was selected for subsequent analysis using the indicator strains of genus Staphylococcus.

\section{Extraction and bioassay-guided fractionation}

The frozen sponge $P$. citrina (4.86 g) was lyophilized and extracted with $200 \mathrm{~mL}$ of methanol/ water $(9: 1)$ at room temperature. The crude extract was partitioned between $n$-hexane $(9 x 50 \mathrm{~mL})$, chloroform $(5 \mathrm{x}$ $50 \mathrm{~mL})$ and ethyl acetate $(5 x 50 \mathrm{~mL})$. The solutions were completely evaporated (in a rotatory evaporator under reduced pressure) to give the respective fractions, $n$-hexane (897.8 mg), chloroform (271.7 mg), ethyl acetate (255.1 $\mathrm{mg}$ ) and aqueous phase (1.09 g). All organic solvents used were of analytical grade. Antibacterial activity of all filtered fractions $(125 \mathrm{mg} / \mathrm{ml})$ was assayed as described previously by Giambiagi-deMarval et al., (1990).

\section{Determination of Minimum Inhibitory Concentration (MIC)}

Antimicrobial activity is measured by determined the smallest amount of agent needed to inhibit the growth of a test microorganism, a value called MIC. The MIC was evaluated by the dilution method in Mueller-Hinton broth (Difco) medium, according to CLSI (2006), for the sponge selected and with different concentrations of active fraction. Bacteria $(104 \mathrm{CFU} / \mathrm{mL})$ were inoculated in the broth with active fraction, and incubated at $37^{\circ} \mathrm{C}$ for 18 h.

\section{Determination of Minimum Bactericidal Concentration (MBC)}

MBC is the smallest concentration of the drug necessary for elimination of $99.9 \%$ of the microorganisms tested. The MBC was determined after the MIC assays. In tubes where MIC results showed no bacterial growth, an aliquot of $0.1 \mathrm{~mL}$ was seeded in Mueller-Hinton agar without addition of drugs and the bacterial growth was evaluated for the $\mathrm{MBC}$ determination. After $18 \mathrm{~h}$ at $37^{\circ} \mathrm{C}$, if $\mathrm{MIC}=\mathrm{MBC}$ or if $\mathrm{MBC}=1,2$ or 3 dilutions above MIC, the activity is considered bactericidal (Isenberg, 1992).

\section{Effects of antibacterial active fraction from $P$. citrina}

The active fraction (final concentration MIC value) from $P$. citrina was sterile filtered and it was added to early log growth phase cells of $S$. aureus $42 \mathrm{AE}$ in 20 $\mathrm{mL}$ BHI medium. A culture in early log growth phase cells of S. aureus $42 \mathrm{AE}$ in $20 \mathrm{~mL} \mathrm{BHI}$ medium without antibacterial fraction or sterile BHI medium were added to control. The cultures were then either maintained at $37^{\circ} \mathrm{C}$ and at $1 \mathrm{~h}$ intervals, the O.D. of $600 \mathrm{~nm}$ were determined.

\section{Analysis of protein synthesis by SDS-PAGE}

Overnight cultures of $S$. aureus ATCC 29213, S. aureus 42AE, S. epidermidis ATCC 1228 or S. epidermidis $70 \mathrm{~S}$ were diluted in $\mathrm{BHI}$ to $107 \mathrm{CFU} / \mathrm{mL}$ and incubated for $1 \mathrm{~h}$ at $37^{\circ} \mathrm{C}$. For labeling, cells were concentrated to $108 \mathrm{CFU} / \mathrm{mL}$ in a methionine-free medium (MEM, Gibco) containing $200 \mu \mathrm{Ci} / \mathrm{mL}$ of $[35 \mathrm{~S}]$ methionine (Amershan) and subject to active fraction addition $(16 \mu \mathrm{g} / \mathrm{mL})$ at 37 ${ }^{\circ} \mathrm{C}$. Samples controls were maintained at $37{ }^{\circ} \mathrm{C}$ without inhibitory fraction addition. In all the tests, the cells were labeled for $1 \mathrm{~h}$ and collected by centrifugation at 12,000 $\mathrm{g}$ for $5 \mathrm{~min}$. The cells were lysed with the addition of 40 $\mathrm{ng} / \mathrm{mL}$ of lysostaphin (Sigma) during $2 \mathrm{~h}$ at $37{ }^{\circ} \mathrm{C}$. After incubation period, equal volumes of $0.5 \mathrm{M}$ Tris- $\mathrm{HCl}(\mathrm{pH}$ 7.2) buffer containing 4\% SDS, $10 \% \beta$-mercaptoethanol, $20 \%$ glycerol and $0.1 \%$ bromophenol blue were added, and the samples were boiled for $5 \mathrm{~min}$ (Laport et al., 2001). Aliquots from each set of samples were subjected to SDS-10\% polyacrylamide pel electrophoresis (PAGE) as described by Ausubel et al., (1997), loading an amount corresponding to an equal number of cells onto each lane. Gels were stained with Coomassie blue, destained, dried, and exposed to X-ray film. 


\section{RESULTS}

\section{Antibacterial activity}

Ten of the twelve sponge species tested demonstrated inhibitory activity against at least one bacterial strain (Tables 2-3). Only Hymeniacidon heliophila and Oceanapia nodosa were inactive against all strains tested. Cliona celata complex was active against Corynebacterium fimi NCTC 7547 only (Table 2). Six sponge species showed significant antibacterial activity against antibiotic-resistant bacteria, including, VRE and MRSA strains (Table 3).

Aqueous extracts of Petromica citrina and Cinachyrella sp. presented the largest action spectra: they inhibited $64 \%$ and $50 \%$ of the 44 bacterial strains tested, respectively (Tables 2-3). Most strains inhibited by these sponges were Gram-positive cocci, including VRE, MRSA, MRSE and various others CNS strains.

The aqueous extract of $P$. citrina inhibited growth of nineteen clinical strains, being ten antibioticresistant strains, including S. aureus, CNS, Enterococcus faecalis and Escherichia coli. As this extract showed the best spectra on antibiotic-resistant strains and very little date about this specie were published, it was selected for subsequent analysis.

\section{Extraction and bioassay-guided fractionation}

Antibacterial activity of all fractions from aqueous extract of $P$. citrina was assayed on reference and clinical strains, being the active aqueous fraction. The results showed a similar spectrum of inhibition those observed with crude extract, being inhibited mainly $S$. aureus and CNS strains. Moreover, inhibitory activity of active fraction was higher at about 0.5 -fold when compared to inhibitory activity of crude extract. The Figure 1 shows the antibacterial effect of aqueous fraction on $S$. aureus 42AE.

\section{MIC and MBC determination}

The MIC of active fraction of $P$. citrina over $S$. aureus $42 \mathrm{AE}$ was $16 \mu \mathrm{g} / \mathrm{mL}$ and the $\mathrm{MBC}$ was ${ }^{3} 64 \mu \mathrm{g} /$ $\mathrm{mL}$. This value indicates bactericidal activity of aqueous fraction of $P$. citrina, because MBC was two dilutions above MIC.

\section{Effect of the inhibitory active fraction on $S$. aureus}

Studies were conducted to examine the effect of active fraction from $P$. citrina upon the growth of $S$. aureus 42AE. Addition of active fraction at the MIC (16 $\mu \mathrm{g} / \mathrm{mL}$ ) to log-phase cultures resulted in a $90 \%$ decrease of absorbance in comparative analysis with the control sample (without active fraction addition) (Figure 2).

\section{Analysis of protein synthesis}

To investigate a possible mechanism of action of antibacterial fraction from $P$. citrina, radiolabelling studies were performed to determine if active fraction, at $16 \mu \mathrm{g} / \mathrm{mL}$, induced an inhibition protein biosynthesis. The autoradiography showed that aqueous fraction inhibited a total protein synthesis of all strains tested, including reference and antibiotic-resistant strains (Figure 3).

\section{DISCUSSION}

The discovery of new antibiotics is important due to the increasing incidence of multiple-resistance of pathogenic microorganisms to drugs that are currently in clinical use (Burgess et al., 1999). Marine sponges are among the most promising sources of new antimicrobial substances. Although Brazil has the world's second most extensive coastline after Australia, the development of the chemistry and pharmacology of Brazilian marine organisms has been hampered for many years because the main focus of Brazilian natural product chemists has been directed to the study of medicinal plants and microorganisms. Only recently, a few Brazilian research groups have focused on the chemistry of marine organisms (Torres et al., 2002; Berlinck et al., 2004; Seleghim et al., 2007). Our results add new information to the growing database of known biological activities of Brazilian sponges.

In this study, ten out of twelve sponge species screened exhibited antibacterial activity. This high percentage, $83 \%$, of active species was also found in other screenings for antimicrobial-active sponge species, independently of the geographical region (Bergquist \& Bedford, 1978; Amade et al., 1982, 1987; Thompson et al., 1985; Uriz et al., 1991; Muricy et al., 1993; Monks et al., 2002; Berlinck et al., 2004; Seleghim et al., 2007). Few studies have shown a lower percentage of active species in antimicrobial assays (e.g., 20\% in Monks et al., 2002). Activity against antibiotic-resistant bacteria is much less common, in the order of $3-15 \%$ of the species tested (Seleghim et al., 2007). Seven out of twelve sponges from Rio de Janeiro (58.3\%) were active against such resistant bacteria, a high percentage when compared with other studies. Probably, the methodologies used by other authors (e.g., Monks et al., 2002; Torres et al., 2002 and Seleghim et al., 2007) may be not as sufficiently sensitive as the methodology described by Giambiagi-deMarval et al., (1990), where each crude extract of sponge was spotted on the surface of agar, instead of using filter paper discs impregnated with the crude extracts. The general problems inherent to antimicrobial screening of plant extracts have been reviewed by Cos et al., (2006).

Six sponge species, Cinachyrella sp., Guitarra sepia, Haliclona sp., M. microsigmatosa, P. citrina and $T$. ignis, showed significant antibacterial activity against antibiotic-resistant bacteria, including E. coli, VRE, 
MRSA, MRSE and various others CNS strains. These bacteria species are the most isolated in hospital infections in the world (Goldrick, 2004).

In the present work, the sponge species with potential for research of antibacterial substances were $P$. citrina and Cinachyrella sp. These species were active against bacteria of medical importance, including fourteen reference strains and 21 strains isolated from hospital patients. Aqueous extract of $P$. citrina inhibited growth of ten antibiotic-resistant strains, including strains of $E$. coli, S. aureus, CNS, and E. faecalis. Moreover, P. citrina extract inhibited ten reference strains, including $S$. aureus, CNS, E. faecalis and M. tuberculosis. Surprisingly, specimens of P. citrina from Santa Catarina state (South Brazil) showed antichemotatic and cytotoxic properties, but no activity against the five bacterial strains tested (E. coli, S. aureus, S. epidermis, B. subtilis, and M. luteus) (Monks et al., 2002). This discrepancy may be due either to differences in extraction or bioassay protocols, or to a natural variability in the concentration of the active substances or fractions. Natural variations in chemical profiles are commonly found in sponges (reviewed in Thoms \& Schupp, 2007).

Table 2. Antibacterial activity of crude extracts from marine sponges against reference strains.

\begin{tabular}{|c|c|c|c|c|c|c|c|c|c|c|c|c|}
\hline Bacteria & & & & & & & nges & & & & & \\
\hline Reference strains & Cin.sp & C.cel & D.ret & G.cor & G.sep & Hal.sp & H.hel & M.mic & O.nod & P. cit & P. jan & T.ign \\
\hline $\begin{array}{l}\text { Acinetobacter calcoaceticus } \\
\text { ATCC } 14293\end{array}$ & - & - & - & - & - & - & - & - & - & - & - & - \\
\hline $\begin{array}{l}\text { Corynebacterium fimi } \\
\text { NCTC } 7547\end{array}$ & $+\mathrm{A}, \mathrm{E}$ & $+\mathrm{A}$ & $+\mathrm{A}$ & $+\mathrm{A}, \mathrm{E}$ & $+\mathrm{A}, \mathrm{E}$ & $+\mathrm{A}, \mathrm{E}$ & - & $+\mathrm{A}$ & - & $+\mathrm{A}, \mathrm{E}$ & $+\mathrm{A}, \mathrm{E}$ & $+\mathrm{A}, \mathrm{E}$ \\
\hline $\begin{array}{l}\text { Enterobacter cloacae } \\
\text { ATCC } 25355\end{array}$ & - & - & - & - & - & - & - & - & - & - & - & - \\
\hline $\begin{array}{l}\text { Enterococcus faecium } \\
\text { ATCC } 19434\end{array}$ & - & - & - & - & - & - & - & - & - & - & - & - \\
\hline $\begin{array}{l}\text { Escherichia coli } \\
\text { ATCC } 25922\end{array}$ & $+\mathrm{E}$ & - & - & - & - & - & - & - & - & - & - & - \\
\hline $\begin{array}{l}\text { Klebsiella pneumoniae } \\
\text { ATCC } 700603\end{array}$ & $+\mathrm{E}$ & - & - & - & - & - & - & - & - & - & - & - \\
\hline Micrococcus luteus ATCC 4698 & $+\mathrm{A}, \mathrm{E}$ & - & $+\mathrm{A}$ & $+\mathrm{A}, \mathrm{E}$ & $+\mathrm{A}, \mathrm{E}$ & $+\mathrm{A}, \mathrm{E}$ & - & $+\mathrm{A}$ & - & $+\mathrm{A}, \mathrm{E}$ & - & $+\mathrm{A}, \mathrm{E}$ \\
\hline $\begin{array}{l}\text { Mycobacterium tuberculosis } \\
\text { H37Rv }\end{array}$ & - & $\mathrm{nt}$ & nt & $\mathrm{nt}$ & nt & - & nt & - & nt & $+\mathrm{A}$ & $\mathrm{nt}$ & nt \\
\hline $\begin{array}{l}\text { Pseudomonas aeruginosa } \\
\text { ATCC } 27853\end{array}$ & - & - & - & - & - & - & - & - & - & - & - & - \\
\hline $\begin{array}{l}\text { Staphylococcus aureus } \\
\text { ATCC } 29213\end{array}$ & $+\mathrm{A}, \mathrm{E}$ & - & - & - & $+\mathrm{E}$ & $+\mathrm{E}$ & - & $+\mathrm{A}, \mathrm{E}$ & - & $+\mathrm{A}, \mathrm{E}$ & $+\mathrm{A}$ & $+\mathrm{E}$ \\
\hline $\begin{array}{l}\text { Staphylococcus aureus } \\
\text { ATCC } 25923\end{array}$ & - & - & - & - & - & - & - & $+\mathrm{A}$ & - & $+\mathrm{A}, \mathrm{E}$ & - & - \\
\hline $\begin{array}{l}\text { Staphylococcus cohnni } \\
\text { ATCC } 29974\end{array}$ & $+\mathrm{A}, \mathrm{E}$ & - & - & - & - & - & - & - & - & $+\mathrm{A}$ & - & - \\
\hline $\begin{array}{l}\text { Staphylococcus epidermidis } \\
\text { ATCC } 12228\end{array}$ & $+E$ & - & - & - & $+\mathrm{E}$ & $+\mathrm{E}$ & - & - & - & $+\mathrm{A}$ & - & $+E$ \\
\hline $\begin{array}{l}\text { Staphylococcus haemolyticus } \\
\text { CCM } 2737\end{array}$ & $+\mathrm{A}, \mathrm{E}$ & - & - & - & $+\mathrm{E}$ & - & - & $+\mathrm{A}$ & - & - & - & - \\
\hline $\begin{array}{l}\text { Staphylococcus hominis } \\
\text { ATCC23844 }\end{array}$ & $+\mathrm{A}, \mathrm{E}$ & - & - & - & - & - & - & $+\mathrm{A}$ & - & - & - & - \\
\hline $\begin{array}{l}\text { Staphylococcus lugdunensis } \\
\text { DSM } 4804\end{array}$ & - & - & - & - & - & - & - & $+\mathrm{A}$ & - & $+\mathrm{A}$ & $+\mathrm{A}$ & - \\
\hline $\begin{array}{l}\text { Staphylococcus schleiferi } \\
\text { DSM4807 }\end{array}$ & $+\mathrm{A}, \mathrm{E}$ & - & - & - & - & - & - & $+\mathrm{A}$ & - & $+\mathrm{A}$ & - & - \\
\hline $\begin{array}{l}\text { Staphylococcus simulans } \\
\text { ATCC } 27851\end{array}$ & $+\mathrm{A}, \mathrm{E}$ & - & - & - & - & - & - & $+\mathrm{A}$ & - & $+\mathrm{A}$ & $+\mathrm{A}$ & - \\
\hline
\end{tabular}

\section{Controls}

Distilled water

Ethanol

+, Inhibition; -, no inhibition; nt, not tested. A, aqueous extract; E, ethanolic extract. Sponge species: Cin.sp, Cinachyrella sp.; C.cel, Cliona celata complex; D.ret, Dragmacidon reliculatus; G.cor, Geodia corticostylifera; G.sep, Guitarra sepia; Hal.sp, Haliclona sp.; H.hel, Hymeniacidon heliophila; M.mic, Mycale microsigmatosa; O.nod, Oceanapia nodosa; P.cit, Petromica citrina; P.jan, Polymastia janeirensis; T.ign, Tedania ignis. 
Table 3. Antibacterial activity of crude extracts from marine sponges against clinical strains.

\begin{tabular}{|c|c|c|c|c|c|c|c|c|c|c|c|c|}
\hline Bacteria & & & & & & Spc & gges & & & & & \\
\hline Clinical strains $\left(\mathrm{R}^{*}\right)$ & Cin.sp & C.cel & D.ret & G.cor & G.sep & Hal.sp & H.hel & M.mic & O.nod & P. cit & P. jan & T.ign \\
\hline Acinetobacter calcoaceticus & $+\mathrm{E}$ & - & - & - & - & - & - & - & - & $+\mathrm{A}$ & - & - \\
\hline Citrobacter freundii & - & - & - & - & - & - & - & - & - & - & - & - \\
\hline $\begin{array}{l}\text { Enterobacter cloacae } 43 \mathrm{AE} \\
(\mathrm{AP}, \mathrm{CFO}, \mathrm{CT}, \mathrm{TT})\end{array}$ & - & - & - & - & - & - & - & - & - & - & - & - \\
\hline Enterobacter hafnia & - & - & - & - & - & - & - & - & - & $+\mathrm{A}$ & - & - \\
\hline $\begin{array}{l}\text { Enterococcus faecalis OG1X } \\
\text { (STR) }\end{array}$ & - & - & - & - & - & - & - & - & - & - & - & - \\
\hline $\begin{array}{l}\text { Enterococcus spp. A256 (VC, } \\
\text { TEI) }\end{array}$ & $+\mathrm{A}$ & - & - & - & $+\mathrm{E}$ & $+\mathrm{E}$ & - & $+\mathrm{A}$ & - & - & - & $+\mathrm{E}$ \\
\hline $\begin{array}{l}\text { E. faecalis V583 (VC, ET, CLO, } \\
\mathrm{KN} \text { ) }\end{array}$ & - & - & - & - & - & $+\mathrm{E}$ & - & $+\mathrm{A}$ & - & $+\mathrm{A}$ & - & $+\mathrm{A}$ \\
\hline $\begin{array}{l}\text { Escherichia coli 54AE (AP, } \\
\text { CLO, SXT, TT) }\end{array}$ & $+\mathrm{E}$ & - & - & - & - & - & - & - & - & $+\mathrm{A}$ & - & - \\
\hline Klebsiella pneumoniae & - & - & - & - & - & - & - & - & - & - & - & - \\
\hline $\begin{array}{l}\text { Pseudomonas aeruginosa } 2 \mathrm{AE} \\
(\mathrm{AZ}, \mathrm{P} / \mathrm{T})\end{array}$ & - & - & - & - & - & - & - & - & - & - & - & - \\
\hline $\begin{array}{l}\text { Staphylococcus aureus } 42 \mathrm{AE} \\
\text { (PN, AP, OX) }\end{array}$ & - & - & - & - & $+\mathrm{E}$ & $+\mathrm{A}, \mathrm{E}$ & - & $+\mathrm{A}, \mathrm{E}$ & - & $+\mathrm{A}$ & $+\mathrm{A}$ & $+\mathrm{E}$ \\
\hline $\begin{array}{l}\text { Staphylococcus aureus } 1 \mathrm{Hp} \\
\text { (PN) }\end{array}$ & $+\mathrm{A}, \mathrm{E}$ & - & - & - & - & - & - & - & - & $+\mathrm{A}, \mathrm{E}$ & - & - \\
\hline Staphylococcus aureus 3Нр & $+\mathrm{A}$ & - & - & - & - & - & - & - & - & $+\mathrm{A}, \mathrm{E}$ & - & - \\
\hline $\begin{array}{l}\text { Staphylococcus aureus } 47 \mathrm{Hp} \\
\text { (PN) }\end{array}$ & $+\mathrm{A}, \mathrm{E}$ & - & - & - & - & - & - & - & - & $+\mathrm{A}$ & - & - \\
\hline Staphylococcus cohnni 9S & $+\mathrm{A}, \mathrm{E}$ & - & - & - & - & - & - & - & - & $+\mathrm{A}$ & - & - \\
\hline Staphylococcus cohnni 242S & $+\mathrm{A}, \mathrm{E}$ & - & - & - & - & - & - & - & - & $+\mathrm{E}$ & - & - \\
\hline Staphylococcus cohnni 338S & $+\mathrm{A}$ & - & - & - & - & - & - & - & - & $+\mathrm{A}, \mathrm{E}$ & - & - \\
\hline $\begin{array}{l}\text { Staphylococcus epidermidis } 57 \mathrm{~S} \\
\text { (PN, CIP, AP, TT) }\end{array}$ & $+\mathrm{A}$ & - & - & - & - & - & - & - & - & $+\mathrm{A}$ & - & - \\
\hline $\begin{array}{l}\text { Staphylococcus epidermidis } 70 \mathrm{~S} \\
\text { (PN, AP, OX, CFO, CR, KN, } \\
\text { GN, IMP, CIP) }\end{array}$ & $+\mathrm{A}$ & - & - & - & - & - & - & - & - & $+\mathrm{A}$ & - & - \\
\hline $\begin{array}{l}\text { Staphylococcus epidermidis } \\
207 \mathrm{~S}\end{array}$ & $+\mathrm{A}$ & - & - & - & - & - & - & $+\mathrm{A}$ & - & $+\mathrm{A}$ & - & - \\
\hline $\begin{array}{l}\text { Staphylococcus haemolyticus } \\
89 \mathrm{~S}\end{array}$ & $+\mathrm{A}$ & - & - & - & - & - & - & - & - & $+\mathrm{A}$ & - & - \\
\hline $\begin{array}{l}\text { Staphylococcus haemolyticus } \\
\text { 179S }\end{array}$ & $+\mathrm{A}$ & - & - & - & - & - & - & - & - & $+\mathrm{A}$ & - & - \\
\hline $\begin{array}{l}\text { Staphylococcus hominis } 60 \mathrm{~S} \\
\text { (TT) }\end{array}$ & $+\mathrm{A}, \mathrm{E}$ & - & - & - & - & - & - & - & - & $+\mathrm{A}$ & - & - \\
\hline $\begin{array}{l}\text { Staphylococcus hominis 79S } \\
\text { (PN, AP) }\end{array}$ & $+\mathrm{A}, \mathrm{E}$ & - & - & - & - & - & - & - & - & $+\mathrm{A}$ & - & - \\
\hline Staphylococcus hominis $178 \mathrm{~S}$ & $+\mathrm{A}$ & - & - & - & - & - & - & - & - & $+\mathrm{A}$ & - & - \\
\hline $\begin{array}{l}\text { Staphylococcus simulans } 188 \mathrm{~S} \\
\text { (CR, ET) }\end{array}$ & - & - & - & - & - & - & - & $+\mathrm{A}$ & - & $+\mathrm{A}$ & - & - \\
\hline \multicolumn{13}{|l|}{ Controls } \\
\hline Distilled water & - & - & - & - & - & - & - & - & - & - & - & - \\
\hline Ethanol & - & - & - & - & - & - & - & - & - & - & - & - \\
\hline
\end{tabular}

+ Inhibition; - no inhibition; A aqueous extract; E ethanolic extract; CNS coagulase-negative staphylococci. Species of sponges as in Table 2. Clinical strains ( $\mathrm{R}^{*}$ ) resistant to: AP, ampicillin; AZ, aztreonam; CFO, cefoxitin; CIP: ciprofloxacin; CLO, chloramphenicol; CR, ceftriaxone; CT, cephalothin; ET, erythromycin; GN, gentamicin; IMP, imipenem; KN, kanamycin; OX, oxacillin; PN, penicillin; $\mathrm{P} / \mathrm{T}$, piperacillin/tazobactam; STR, streptomycin; SXT, trimethoprim/sulfamethoxazol; TEI, teicoplanin; TT, tetracycline; VC, vancomycin. 
The other sponge species screened that demonstrated antibacterial activity against resistantbacteria were G. sepia, Haliclona sp., M. microsigmatos and T. ignis. All these species inhibited VRE and MRSA strains. Three of these sponge species have already been found antibacterial activity in crude extracts (Muricy et al., 1993; Seleghim et al., 2007). However, this is the first time that antibacterial activity from $G$. sepia is documented.

In this study, extracts of sponges with antibacterial activity showed a large action spectrum against Grampositive cocci. It has been well-established that Grampositive bacteria are much more sensitive to drug action

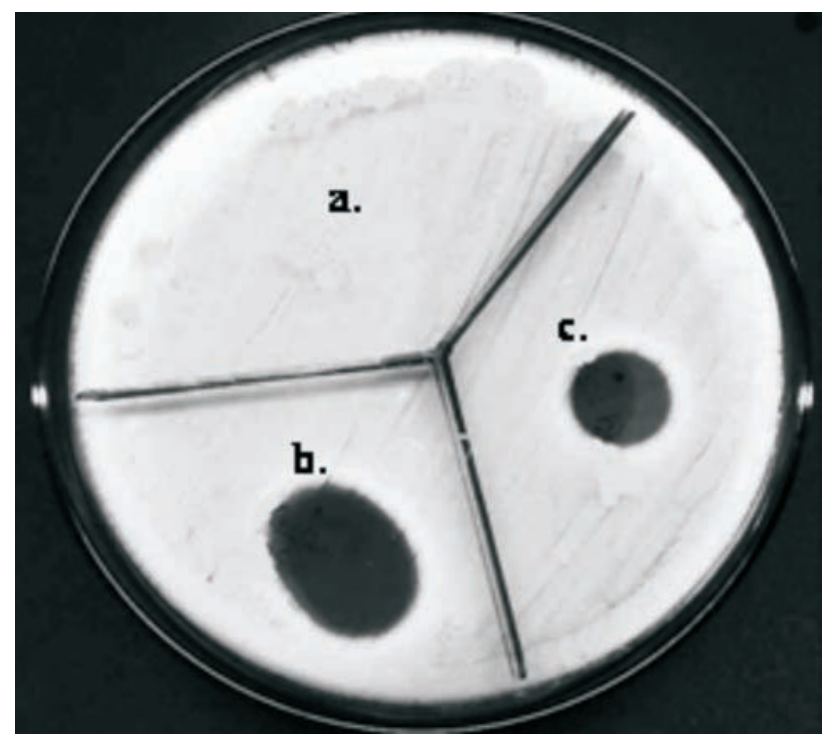

Figure 1. Antibacterial effect of aqueous fraction from extract P. citrina on S. aureus 42AE. (a) water, negative control; (b) test: aqueous fraction, inhibition zone around spot at $25 \mathrm{~mm}$; (c) positive control: aqueous extract, inhibition zone around spot at $16 \mathrm{~mm}$. than Gram-negative bacteria (Cos, 2006). Gram-positive cocci such as S. aureus, CNS, and Enterococcus spp. are extremely important pathogens in hospital environments. The number of strains of these species that are resistant to standard antibiotics has increased, leading to increased morbidity and mortality in nosocomial infections. In some cases, such as hospital-acquired MRSA, infection control measures appear to be the most important mechanisms for limiting spread. In others, such as VRE, both infection control and antimicrobial exposures are important (Rice, 2006). New antibacterial agents effective for treating serious Gram-positive infections are also highly needed.

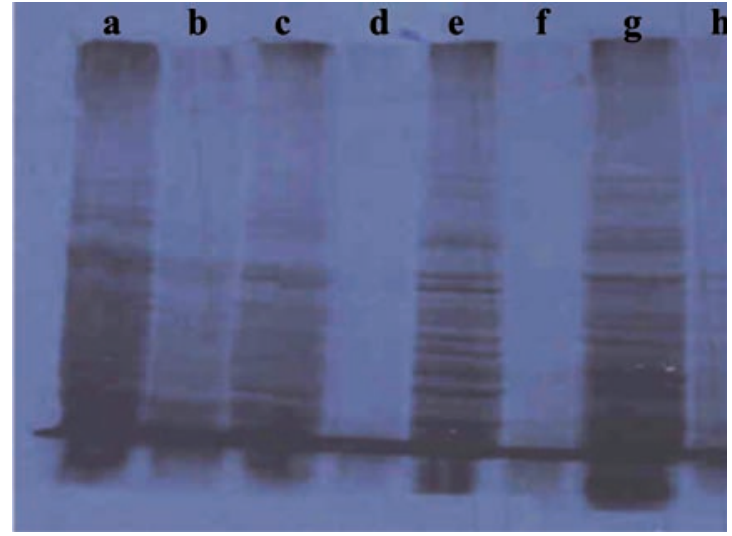

Figure 3. Influence of activity fraction from $P$. citrina on protein synthesis. Autoradiogram of a SDS-PAGE protein profile of the S. aureus ATCC 29213 (a,b), S. aureus 42AE (c,d), S. epidermidis ATCC 1228 (e,f) or S. epidermidis 70S (g,h) strains labeled in the presence of $[35 \mathrm{~S}] \mathrm{Met}(200 \mu \mathrm{Ci} / \mathrm{mL})$ for $1 \mathrm{~h}$ at $37^{\circ} \mathrm{C}$. Control cells (lanes a, c, e, g) or cells treated with inhibitory fraction $(16$ $\mu \mathrm{g} / \mathrm{mL}$ ) (lanes b, d, f, h).

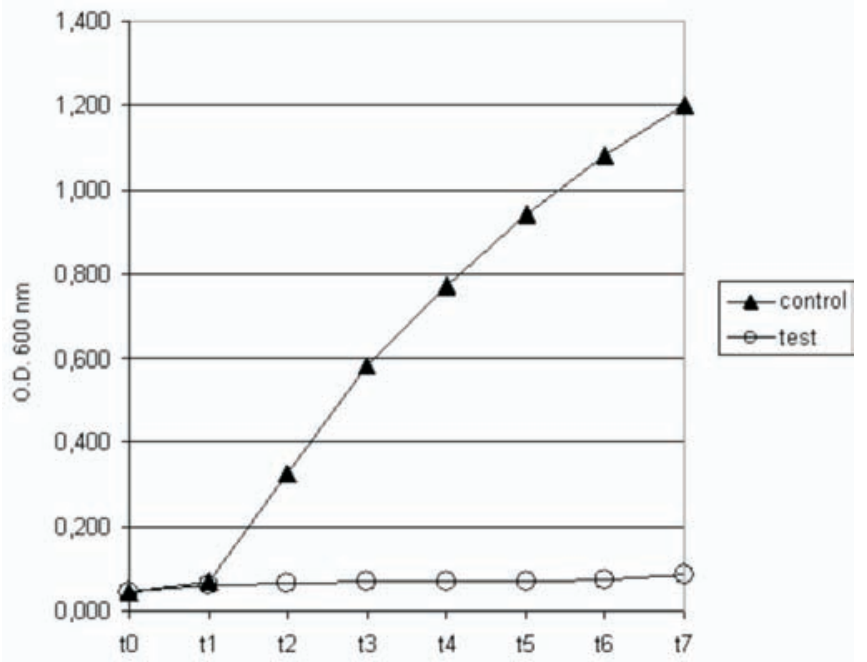

Figure 2. Effects of antibacterial activity of aqueous fraction from $P$. citrina on $S$. aureus 42AE. The cultures treated with inhibitory fraction (circle) or control (triangle) were then either maintained at $37{ }^{\circ} \mathrm{C}$ and at $1 \mathrm{~h}$ intervals, the O.D. of $600 \mathrm{~nm}$ were determined. Each point represents the mean of three independent experiments. 
Our results indicate at least one promising new candidate for research of antibacterial substances. Fractionation of the crude extract from $P$. citrina showed activity of aqueous fraction. This fraction presented inhibitory effects on Staphylococcus sp., including MRSA strain isolated from a hospital. Moreover, bacterial protein synthesis was inhibited by substances present in the aqueous phase. This effect could be a direct mode of action or the active fraction could interfere with the integrity of the cell wall or the cytoplasmic membrane. In the latter case, the effect could cause the efflux of small molecules (for example, potassium and amino acids) and dissipation of the membrane potential, resulting in an arrest of all cellular biosyntheses. Therefore, inhibited protein biosynthesis could be a secondary effect. Few studies showed the mode of action of antibacterial substances isolated from sponges. A study with the sceptrin, an antimicrobial agent isolated from the Agelas mauritiana, showed a mechanism of action on the cell wall with subsequent damage to the membrane (Bernan et al., 1993). Future studies investigating the possible role of antibacterial substance from $P$. citrina on growth bacteria would provide greater insight into the precise mechanism of action of this antibiotic. In addition, the aqueous fraction is currently being studied chemically for identification of the active substance with the aim to use it to treat multiresistant-bacteria infections in the future.

\section{ACKNOWLEDGEMENTS}

The authors specially thank Dra. Kátia Regina Netto dos Santos and Dra. Maria do Carmo de Freire Bastos (UFRJ, Brazil) for encouragement, bacterial strains and laboratory facilities and Dr. Walter Oelemann for their assistance in the preparation of this manuscript. This work was supported by grant from FUJB - ALV2005 and FAPERJ to M.S. Laport. P. R. Marinho was recipient CNPq - PIBIC fellowship. G. Muricy was supported by grants from FAPERJ and CNPq.

\section{REFERENCES}

Amade PG, Chariou G, Baby C, Vacelet J 1987. Antimicrobial activity of marine sponges of Mediterranean. Sea Mar Biol 94: 271-275.

Amade PH, Pesando D, Chevolot L 1982. Antimicrobia activity of marine sponges from French Polynesia and Brittany. Mar Biol 70: 223-228.

Aneiros A, Garateix A 2004 Bioactive peptides from marine sources: pharmacological properties and isolation procedures. J Chromatogr B 803: 41-53.

Ausubel FM, Brent R, Kingston RE, Moore DD, Sidman JG, Smith K 1994-1997. Current Protocols in Molecular Biology. Vol 2, ch 10. New York: Wiley Interscience, p. 10.0.5-10.20.13.

Becerro MA, Thacker RW, Turon X, Uriz MJ, Paul VJ 2003. Biogeography of sponge chemical ecology: comparisons of tropical and temperate defenses. Oecologia 135: 91101.

Bergquist P, Bedford JJ 1978. The incindence of antibacterial activity in marine Demospongiae: systematic and geographical considerations. Mar Biol 46: 215-221.

Berlinck RGS, Hajdu E, Rocha RM, Oliveira JHHL, Hernandez ILC, Seleghim MHR, Granato AC, Almeida EVR, Nunez CV, Muricy G, Peixinho S, Pessoa C, Moraes MO, Cavalcanti BC, Nascimento GGF, Thiemann O, Silva M, Souza AO, Silva CL, Minarini PRR 2004. Challenges and rewards of research in marine natural products chemistry in Brazil. J Nat Prod 67: 510-522.

Bernan VS, Roll DM, Ireland CM, Greenstein M, Maiese WM, Steinberg DA 1993. A study on the mechanism of action of sceptrin, an antimicrobial agent isolated from the South Pacific sponge Agelas mauritiana. J Antimicrob Chemother 32: 539-550.

Blunt JW, Copp BR, Hu WP, Munro MH, Northcote PT, Prinsep MR 2007. Marine natural products. Nat Prod Rep 24: 3186

Burgess JG, Jordan EM, Bregu M, Mearns-Spragg A, Boyd KG 1999. Microbial antagonism: a neglected avenue of natural products research. J Biotechnol 70: 27-32.

CLSI (Clinical and Laboratory Standards Institute) 2006. Methods for Dilution Antimicrobial Susceptibility Tests for Bacteria That Grow Aerobically; Approved Standard. Seventh Edition (M7-A7). NCCLS, Wayne PA.

Cos P, Vlietinck AJ, Berghe DV, Maes L 2006. Anti-infective potential of natural products: How to develop a stronger in vitro "proof-of-concept”. J Ethnopharmacol 106: 290302.

Diekema DJ, Pfaller MA, Schmitz FJ, Smayevsky J, Bell J, Jones RN, Beach M, Sentry Partcipants Group 2001. Survey of infections due to Staphylococcus species: frequency of occurrence and antimicrobial susceptibility of isolates collected in the United States, Canada, Latin America, Europe, and the Western Pacific region for the SENTRY Antimicrobial Surveillance Program, 1997-1999. Clin Infect Dis 32: S114-132.

Farr BM 2006. What to think if the results of the National Institutes of Health Randomized Trial of MethicillinResistant Staphylococcus aureus and VancomycinResistant Enterococcus Control Measures are negative (and other advice to young epidemiologists): a review and an au revoir. Infect Control Hosp Epidemiol 27: 1096-1106

Gerwick WH 1987. Drugs from the sea: The search continues. $J$ Pharm Technol 3:136-141.

Giambiagi-deMarval M, Mafra MA, Penido EGC, Bastos MCF 1990. Distinct groups of plasmids correlated with bacteriocin production in Staphylococcus aureus. J Gen Microbiol 136: 1591-1599.

Goldrick BA 2004. Emerging infections. Am J Nurs 104: 50-51. Isenberg HD 1992. Clinical Microbiology Procedures Handbook. Vol 1, Sec 5.16. Washington, DC: ASM.

Kobayashi M 2000. Search for biologically active substances 
from marine sponges. In: Fusetani N (ed) Drugs from the Sea. Basel: Karger, p.46-58.

Laport MS, Castro ACD, Villardo A, Lemos JAC, Bastos MCF, Giambiagi-deMarval M 2001. Expression of the Major Heat Shock Proteins DnaK and GroEL in Streptococcus pyogenes: A Comparison to Enterococcus faecalis and Staphylococcus aureus. Curr Microbiol 42: 264-268.

Laport MS, Santos OCS, Muricy G 2009. Marine sponges: potential sources of new antimicrobial drugs. Curr Pharm Biotechnol 10: 86-105.

Mayer AM, Hamann MT 2004. Marine pharmacology in 2000: marine compounds with antibacterial, anticoagulant, antifungal, anti-inflammatory, antimalarial, antiplatelet, antituberculosis, and antiviral activities; affecting the cardiovascular, immune, and nervous systems and other miscellaneous mechanisms of action. Mar Biotechnol (NY) 6: 37-52.

Monks NR, Lerner C, Henriques AT, Farias FM, Schapoval EES, Suyenaga ES, Rocha AB, Schwartsmann G, Mothes B 2002. Anticancer, antichemotactic and antimicrobial activities of marine sponges collected off the coast of Santa Catarina, Southern Brazil. J Exp Mar Biol Ecol 281: 1-12.

Monteiro LC, Muricy G 2004. Patterns of sponge distribution in Cagarras Arquipelago, Rio de Janeiro, Brazil. J Mar Biol Ass UK 84: 681-687.

Moura RM, QueirozAF, Fook JM, Dias AS, Monteiro NK, Ribeiro JK, Moura GE, Macedo LL, Santos EA, Sales MP 2006. $\mathrm{CvL}$, a lectin from the marine sponge Cliona varians: Isolation, characterization and its effects on pathogenic bacteria and Leishmania promastigotes. Comp Biochem Physiol A Mol Integr Physiol 145: 517-523.

Munro MH, Blunt JW, Dumdei EJ, Hickford SJ, Lill RE, Li S, Battershill CN, Duckworth AR 1999. The discovery and development of marine compounds with pharmaceutical potential. J Biotechnol 70: 15-25.

Muricy G, Hajdu E, Araújo FV, Hagler NA 1993. Antimicrobial activity of Southwestern Atlantic shallow-water marine sponges (Porifera). Sci Mar 57: 427-432.

National Nosocomial Infections Surveillance (NNIS) System Report 2004. Data summary from January 1992 through June 2004. Am J Infect Control 32: 470-485.

Pawlik JR, Chanas B, Toonen RJ, Fenical W 1995. Defenses of caribbean sponges against predatory reef fish. I. Chemical deterrency. Mar Ecol Prog Ser 127: 183-194.

Rangel M, Sanctis B, Freitas JC, Polatto JM, Granato AC, Berlinck RGS, Hajdu E 2001 Cytotoxic and neurotoxic activities in extracts of marine sponges (Porifera) from southeastern Brazilian coast. J Exp Mar Biol Ecol 262: 31-40.

Rice LB 2006. Antimicrobial resistance in Gram-positve bacteria. Am J Infect Control 34: S11-19.

Seleghim MHR, Lira SP, Kossuga MH, Batista T, Berlinck RGS, Hajdu E, Muricy G, Rocha, RM, Nascimento GGF, Silva M, Pimenta EF, Thiemann OH, Oliva G, Cavalcanti BC, Pessoa C, Moraes MO, Galetti FCS, Silva CL, Souza
AO, Peixinho S 2007. Antibiotic, cytotoxic and enzyme inhibitory activity of crude extracts from Brazilian marine invertebrates. Rev Bras Farmacogn 17: 287-318.

Sipkema D, Franssen MC, Osinga R, Tramper J, Wijffels RH 2005. Marine sponges as pharmacy. Mar Biotechnol (NY) 7: 142-162.

Thompson JE, Walker RP, Falkner DJ 1985. Screening and bioassays for biologically active substances from forty marine sponges from San Diego, California, USA. Mar Bio 88: 11-21.

Thoms C, Schupp PJ 2007. Chemical defense strategies in sponges: a review. In: Custódio, MR, Lôbo-Hajdu G, Hajdu E, Muricy G (eds) Porifera Research Biodiversity, Innovation and Sustainability. Rio de Janeiro: Série Livros 28, Museu Nacional, p. 627-637.

Torres YR, Berlink RGS, Nascimento GGF, Fortier SC, Pessoa C, Moraes MO 2002. Antibacterial activity against resistant bacteria and cytotoxicity of four alkaloid toxins isolated from the marine sponge Arenosclera brasiliensis. Toxicon 40: 885-891.

Uriz MJ, Martin D, Turon X, Ballesteros E, Hughes R, Acebal C 1991. Anapproach to the ecological significance of chemically-mediated bioactivity in Mediterranean benthic communities. Mar Ecol Progr Ser 70: 175-188.

Weber SG, Gold HS, Hooper DC, Karchmer AW, Carmeli Y 2003 Fluoroquinolones and the risk for methicillin-resistant Staphylococcus aureus in hospitalized patients. Emerg Infect Dis 9: 1415-1422.

Wulff JL 2006. Sponge systematics by starfish: predators distinguish cryptic sympatric species of Caribbean fire sponges, Tedania ignis and Tedania klausi n. sp. (Demospongiae, Poecilosclerida). Biol Bull 211: 83-94.

Zetola N, Francis JS, Nuermberger EL, Bishai, WR 2005. Community acquiredmethicillin-resistantStaphylococcus aureus: an emerging threat. Lancet Infect Dis 5: 275286. 